\title{
Assessing THE MAINTENANCE OF SAVINGS SUFFICIENCY OVER THE FIRST DECADE OF RETIREMENT
}

\author{
ROBERT HAVEMAN \\ KAREN HOLDEN \\ BARBARA WOLFE \\ ANDREI ROMANOV
}

CESIFO WORKING PAPER NO. 1567

CATEgory 3: SOCIAL PROTECTION

OCTOBER 2005

An electronic version of the paper may be downloaded

- from the SSRN website:

www.SSRN.com

- from the CESifo website:

www.CESifo-group.de 


\title{
Assessing THE MAINTENANCE OF SAVINGS SUFFICIENCY OVER THE FIRST DECADE OF RETIREMENT
}

\begin{abstract}
The adequacy of retirement savings is central to the U.S. debate over the effects of Social Security reform and pension changes that would place greater responsibility on individuals for accumulation of retirement resources. We contribute to this discussion by examining the extent to which individuals maintain initial levels of resources over the first decade of retirement. We compare annuitized wealth, including Social Security and pension wealth, to two consumption standards- a household's preretirement earnings and the poverty threshold. We analyze the relationship of individual characteristics to changes in this ratio over time, including the effects of widowhood and post-retirement work.
\end{abstract}

JEL Code: J14, J26.

Robert Haveman

La Follette School of Public Affairs

University of Wisconsin-Madison

1225 Observatory Drive

Madison, WI 53706-1211

USA

haveman@lafollette.wisc.edu

Barbara Wolfe

Department of Economics

University of Wisconsin-Madison

1180 Observatory Drive

Madison, WI 53726-1393

USA

wolfe@lafollette.wisc.edu
Karen Holden

La Follette School of Public Affairs

University of Wisconsin-Madison

1225 Observatory Drive

Madison, WI 53706-1211

USA

holden@lafollette.wisc.edu

Andrei Romanov

University of Wisconsin-Madison

USA

Paper originally presented at the CEBR/CESifo conference on pension reform, Copenhagen, 2005. This research was partially supported by a grant from the Social Security Administration. Additional support was provided by the Institute for Research on Poverty, the Graduate School and the Center for Demography and Ecology all at the University of Wisconsin-Madison. Conclusions represent those of the authors alone and not of the funding agency. The first three authors contributed equally to the paper; the last conducted most of the calculations. 


\section{Assessing the Maintenance of Savings Sufficiency over the First Decade of Retirement}

\section{INTRODUCTION}

There is considerable public policy concern regarding the savings behavior of U.S. citizens, specifically the low level of personal savings and the ability to accumulate retirement assets sufficient to sustain economic well-being after retirement. In the United States individuals are expected to accumulate retirement assets beyond the basic benefits provided by the federal Old Age and Survivors Insurance program through personal savings in the form of employer-provided pensions, housing, and financial assets. Considerable research and policy attention has been paid to the extent to which private wealth holdings at retirement (which reflect consumption-savings decisions during preretirement years) would enable current and future retirees to meet and sustain consumption during their expected retirement years. Governmental agencies, policy research organizations and the popular press have commented extensively on this issue, and researchers have reached quite different conclusions regarding the adequacy of the resources available to those who are approaching or on the verge of retirement. ${ }^{1}$

In this paper, we examine the maintenance of resources during retirement, asking whether resources and measures of resource adequacy at retirement are sustained over the first decade of retirement or whether during that time resources are consumed at a rate that implies changes in savings adequacy from that estimated when first retired. We study the evolution of retirement resources from the time of retirement (when most respondents are in their mid-to-late sixties) to a date ten years later (when most are in their mid-to-late seventies). We compare potential consumption levels with two "adequacy" criterion as a means of assessing the potential social and individual consequence of a change in resources.

${ }^{1}$ See Engen, Gale, and Uccello (1999) for references to media and governmental analyses of this issue. A report of the U. S. Congressional Budget Office (2003) summarizing recent findings highlights the current policy interest in this issue. 
We describe correlates of falls and increases in resources for the entire group of retirees and demographic subgroups.

\section{PREVIOUS LITERATURE}

A number of studies have assessed and analyzed the adequacy of retirement savings of individuals, using a variety of analytic approaches and standards against which to judge adequacy of available resources if consumed over the expected years of retired life. The majority of studies, including Grad (1990), Bernheim (1992), Moore and Mitchell (2000), Gustman and Steinmeier (1998), Mitchell, Moore and Philips (2000), Engen, Gale, and Uccello (1999) assess retirement savings at or near some expected uniform retirement age, annuitizing estimated resources over the remaining years of life. Taking a different approach, Haveman et al. (2005) assess retirement adequacy for a sample of new Social Security beneficiaries, by comparing the annuitized value of wealth at actual ages of retirement (or benefit receipt), which varied across individuals. None of these studies report on the evolution of the full array of retirement resources during the years after retirement. Wolff (2002) uses the Survey of Consumer Finances for years 1983, 1985, 1989 and 1998 to examine how savings adequacy has changed over time across demographic groups, estimating the annuitized value of wealth at an expected age of retirement. He found, for example, that expected retirement income increased over the period studied for those aged 47-64, while the share of those whose expected retirement income fell below the nation's poverty line increased from 17 to 19 percent. While Wolff concludes that there was a serious shortfall in retirement income at end of the 1990s which increased over time, his conclusions are about cross-cohort differences, not about changes over time for single cohorts.

Conclusions regarding resource adequacy at retirement implicitly assume the annual consumption stream that is enabled by available resources will persist throughout each individual's remaining lifetime. However, such snapshots of savings adequacy ignore variations in adequacy levels during retirement years. Initial levels of adequacy may grow, perhaps intentionally so if individuals explicitly include in 
their retirement plans strategies for continued asset accumulation. Assets may also grow because of the unanticipated receipt of bequests or survivorship benefits from persons other than a spouse, or because post-retirement consumption was slower than expected. Thus, estimated levels of resource adequacy may actually improve over the retirement years for some individuals. Conversely, the level of available resources may deteriorate during the years after retirement because of special needs (e.g., health), unwise investment choices or bad luck. Thus measures of savings adequacy at retirement may provide a misleading picture of who has undersaved and who is financially well prepared for retirement and, therefore, of the retirement savings problem.

\section{OUR RESEARCH APPROACH}

By comparing the picture of adequacy of resources both at the time of retirement and ten years later, we are able to assess how individuals (and couples) fare during their retirement years, and to determine if those with resources at the time of retirement that meet (or do not meet) standards of adequacy maintain that status or change position in systematic ways.

Our sample is from the Social Security Administration's New Beneficiary Survey (NBS), a sample of individuals who first applied for Social Security benefits in 1980-81. The NBS interviewed respondents shortly after first benefit receipt (in 1982) and the surviving members approximately ten years later (in 1991). The NBS survey data are matched to Social Security administrative earnings and benefit records for respondents and benefit-eligible spouses, providing accurate measures of both preretirement covered earnings and unreduced Social Security benefits. ${ }^{2}$ Individuals provided data on current and expected pension benefits as well as on financial and property holdings including, if married, of their

\footnotetext{
${ }^{2}$ Although the surveys were in 1982 and 1991, Social Security administrative records were updated through December 2000 and earnings through 1999, providing data on intra-survey employment.
} 
spouse. With these data we are able to examine the persistence of retirement savings adequacy status over time. ${ }^{3}$ Statistics on the characteristics of this sample are shown in Appendix Table A.

The NBS provides data on the wealth holdings and household structure of a large sample of men and women at the time of their retirement, defined by the first receipt of Social Security retired-worker benefits; hence we do not have to forecast these values from observations at a time prior to retirement. ${ }^{4}$ For each individual and married couple in 1982 and 1991 we estimate net wealth, which is the sum of financial and property resources, the net value of own home (home value less outstanding mortgage), the present discounted values of currently received and expected pension benefits and the present discounted value of full Social Security benefits. ${ }^{5}$

In estimating Social Security wealth as of 1982, we project the monthly inflation-adjusted benefits to which each individual is entitled (obtained from the linked Master Beneficiary File) over the individual's expected remaining lifetime using 1982 race- and gender-specific life tables (U.S. Department of Health and Human Services, 1985), incorporating for married couples program-specific survivorship rules and the probability of being married or only one spouse surviving. We discount this inflation adjusted stream of benefits to 1982 using a 2.75 percent rate, yielding the wealth value of Social Security benefits. The respondent-provided currently received or expected pension benefit amount reflects a nominal value of benefits at the time of interview and, thus we discount this expected stream by a rate that incorporates actual inflation adjustments made to NBS pensioners' benefits. ${ }^{6}$ In calculating couples'

\footnotetext{
${ }^{3}$ The NBS sample is of individuals who first received Social Security benefits between June 1980 and June 1981 (Ycas, 1992). Our sample is of retired-worker beneficiaries age 62-72 in 1982 who were interviewed in both 1982 and 1991. We require reinterview since for some younger spouses of retired-workers data on earnings and on social security and pension benefits are available only in 1991. Attrition of 1982 respondents is analyzed in Antonovics et al. (2002).

${ }^{4}$ Respondent reports provide information on all of these values except Social Security benefits, which are from matched benefits data on both respondents and spouses.

${ }^{5}$ The 1982 NBS does not contain information on indebtedness other than the mortgage on own home, resulting in some overstatement of initial net wealth.

${ }^{6}$ On average pension benefits grew by 3.25 percent between 1982 and 1991 for fully retired NBS pensioners, a rate that is .75 percent less than the 4 percent rate of inflation between those years. We thus use a 3.25 percent rate to discount pension benefit streams to 1982 ( 2.75 percent plus .75 percent).
} 
pension wealth we account for whether the recipient indicated that his or her pension would continue to be paid to a surviving spouse. The Social Security plus pension and Social Security wealth of a couple is the sum of each spouse's wealth where pension and Social Security wealth calculations are over the probable separate and joint survival periods for husband and wife and the benefits expected under each status. $^{7}$

We use these net wealth data to estimate the annuitized value of wealth holdings (ANW) in both years over the estimated remaining years of life of individuals and couples, including the years when only one spouse survives. In this paper we summarize these patterns and show the contributions to changes in wealth and ANW of the financial, home equity, pension and Social Security components of these values. We then assess the adequacy of these resources to meet consumption needs over the years of retirement by comparing ANW to two standards of 'adequacy. The first is a widely accepted standard in the literature-having available retirement income (the ANW value) equal to or greater than 70 percent of preretirement earnings (regarded as the income necessary in order to maintain preretirement consumption). The second is a social criterion of adequacy—having available retirement income (ANW) equal to or greater than poverty and near-poverty levels of income. Finally, we study the relationship of a variety of individual characteristics to changes in the level of resources and resource adequacy from the time of retirement to ten years after retirement. In examining changes in adequacy measures over the 10year period after retirement, we test whether initial "adequacy” status persists into retirement, or if differential consumption, changes in family structure (e.g., death of a spouse), or post-retirement savings and work alters that status over time.

${ }^{7}$ Social Security wealth for married couples is the sum of spousal wealth values. Each spouse's benefit is the higher of: 1) their own retired-worker benefit, or 2) the benefit as a spouse/widow. The value of Social Security benefits are estimated conditional upon remaining married or being a sole survivor, using Social Security survivorship rules. Pension benefits for married couples are estimated using answers that indicated whether a singlelife or some form of survivor benefit was chosen. If a survivor benefit is indicated, a joint and two-thirds (66 percent) survivor benefit is assumed. For younger spouses and those for whom no age of receipt for an expected pension benefit was reported 1982, we used data from the 1992 survey, if available 


\section{WEALTH AND ANNUITIZED WEALTH: 1982 AND 1992}

\section{Patterns of Wealth Levels and Change}

Table 1 shows mean asset (total net wealth) holdings in 1982 and 1991 (in 1994 dollars) of our sample of retired workers, distinguished by gender and marital status. ${ }^{8}$ Table 1 also shows the composition of assets in each year, the percentage change over the period in both total net wealth and its components, and the contribution of changes in the level of each of the components of net wealth to the total change in net wealth.

In 1982, the mean level of assets of both married men and married women exceeds $\$ 500,000$. The asset value of Social Security benefits is about $40-50$ percent of this total, while financial wealth accounts for 20-30 percent. By 1991, mean assets had fallen by about $\$ 150,000$ (30 percent) for married women, and by $\$ 115,000$ (22 percent) for married men. The decrease in Social Security wealth accounts for about half of the 1982-1991 reduction in total assets; a reduction that is largely due to the shorter remaining lifetime in 1991 over which Social Security benefits must be spread in estimating the wealth value of Social Security benefits. ${ }^{9}$ Social Security wealth of married women fell by 37 percent over this period, while for married men it fell by 25 percent, a gender difference due to the greater prevalence of widow(er)hood among women than men. The wealth value of pensions fell by about 25-30 percent from 1982 to 1991, reflecting both the reduced number of years of remaining life over which a pension benefit would be paid as well as reductions due to spousal death. ${ }^{10}$ Financial wealth fell by about one-quarter, suggesting the drawing down of this wealth stock to support living costs during retirement. Interesting, housing wealth remained virtually constant for both married men and women, suggesting that increasing

${ }^{8}$ The NBS drew separate samples of retired-worker women and men. We distinguish those groups here because female retired-worker beneficiaries are different from wives of male retired-worker beneficiaries since by definition they must have sufficient covered work quarters to qualify for Social Security benefits. Likewise male retired-workers are more likely to be full-time and long-term workers than are husbands of female retired workers.

${ }^{9}$ Annual Social Security benefits are a lifetime annuity. The present discounted value of an annuity evaluated over a larger number of years of expected life (as in 1982) will be greater than its present value evaluated over a smaller number of years (as in 1991).

${ }^{10}$ Individual retirement accounts and 401(k) plan accumulations are included in financial assets. 
housing equity offsets movement out of home ownership by retired couples. Pensions and financial wealth contributed about the same percentage to the total decline in wealth among married women and men.

TABLE 1

Mean Household Net Wealth and Components New Retired-Worker Beneficiaries, 1982 and 1991

\begin{tabular}{|c|c|c|c|c|}
\hline Wealth Component & Mean '82 & Mean '91 & \% Change & $\begin{array}{l}\text { Contribution to } \\
\text { Total Change }\end{array}$ \\
\hline & \multicolumn{4}{|c|}{ (thousands of \$1994) } \\
\hline \multicolumn{5}{|l|}{ Married Women } \\
\hline Net Wealth & 502.4 & 350.5 & $-30.2 \%$ & $100.0 \%$ \\
\hline Financial & 111.8 & 80.2 & -28.3 & 20.8 \\
\hline Housing & 72.1 & 71.7 & -0.5 & 0.3 \\
\hline Social Security & 249.0 & 157.6 & -36.7 & 60.1 \\
\hline Pensions & 69.5 & 41.0 & -41.0 & 18.8 \\
\hline \multicolumn{5}{|l|}{ Married Men } \\
\hline Net Wealth & 534.7 & 419.3 & $-21.6 \%$ & $100.0 \%$ \\
\hline Financial & 145.9 & 117.5 & -19.4 & 24.6 \\
\hline Housing & 85.5 & 83.0 & -2.9 & 2.2 \\
\hline Social Security & 230.2 & 172.9 & -24.9 & 49.6 \\
\hline Pensions & 73.2 & 45.9 & -37.3 & 23.7 \\
\hline \multicolumn{5}{|l|}{ Single Women } \\
\hline Net Wealth & 258.0 & 201.5 & $-21.9 \%$ & $100.0 \%$ \\
\hline Financial & $\$ 48.0$ & $\$ 38.9$ & -19.1 & 16.3 \\
\hline Housing & 45.2 & 38.2 & -15.4 & 12.3 \\
\hline Social Security & 125.1 & 99.1 & -20.8 & 46.0 \\
\hline Pensions & 39.7 & 25.3 & -36.4 & 25.5 \\
\hline \multicolumn{5}{|l|}{ Single Men } \\
\hline Net Wealth & 290.8 & 254.3 & $-12.6 \%$ & $100.0 \%$ \\
\hline Financial & 91.8 & 83.4 & -9.2 & 23.0 \\
\hline Housing & 38.5 & 42.7 & 11.0 & -11.6 \\
\hline Social Security & 122.2 & 100.5 & -17.8 & 59.3 \\
\hline Pensions & 38.4 & 27.7 & -28.0 & 29.3 \\
\hline
\end{tabular}


A similar pattern is observed for single men and women. In 1982, single men held about $\$ 291,000$ in assets upon retirement, while single women held $\$ 258,000$. As with married couples, Social Security wealth accounts for the larger share, just under half, of total wealth. A substantial gender disparity in financial wealth exists, with the holdings of single men $(\$ 92,000$, or 32 percent of total wealth) nearly double that of single women ( $\$ 48,000$, or 19 percent of total wealth). Conversely, housing wealth accounts for a larger share of the total wealth of single women (18 percent) than of single men (13 percent).

Over the first ten years of retirement, the wealth of both single men and single women fell; the decrease for single women is 22 percent, and for single men is 13 percent. As with married couples, the decrease in pension and Social Security wealth accounts for the bulk of the reduction in wealth over the decade. It is noteworthy that the percent decrease in pension wealth (by 36 percent for single women and 28 percent for single men) is greater than the fall in Social Security wealth for each group. ${ }^{11}$ For single men, housing wealth actually increased by more than 10 percent over the first ten years of retirement. However, the value of the housing stock of single women housing stock fell by over 15 percent over the 1982-1991 period, reflecting a more rapid rate of exiting home ownership or shifts to lower priced housing.

For all of the groups, the change in Social Security wealth accounted for the major share of the decline in net wealth over the first decade of retirement; its contribution ranged from 46 percent of the overall decrease for single women to 60 percent for married women. Across the groups, decreases in financial wealth accounted for between 16 and 25 percent of the fall in net wealth, while pensions accounted for between 19 and 29 percent of the decrease. The fall in housing wealth accounts for about 12 percent of the decline in net wealth for single women; in contrast, the housing wealth of single men increased, offsetting about 12 percent of the decline in net wealth attributable to the decline in other

\footnotetext{
${ }^{11}$ This differential pattern of pension and Social Security wealth change is likely due to a combination of factors that have negatively affected expected pension benefits, including only partial price indexing, the loss of benefits over time due to limited period payment (e.g., to survivors), and employer-related pension cutbacks.
} 
wealth components. For married couples, housing wealth remained nearly unchanged over the first decade of retirement.

Patterns of Annuitized Net Wealth (ANW) Levels and Change

In Table 2 we show our estimates of the annuitized value of net wealth (ANW) in both 1982 and 1991 (again in 1994 dollars). ${ }^{12}$ In contrast to net wealth, ANW takes account of the remaining years over which wealth must be spread (thus differentiating between the sufficiency of wealth of older and younger retirees with identical net wealth) and of potential changes in the size of the consumption unit, principally the probability that married couples will be widowed by the death of the husband or wife. The ANW estimates for married couples are single-person equivalent values; the values for single and married individuals are directly comparable. ${ }^{13}$

For couples, mean equivalent ANW is between $\$ 23,000$ and $\$ 25,000$ in 1982 , less than that of single men $(\$ 26,000)$, but greater than that of single women $(\$ 19,000)$. For all of the groups the mean level of ANW increased over the first ten years of retirement, with the increase for men (about 12 percent) exceeding that for women ( $2-5$ percent). The percentage increase in annuitized housing wealth is large for all of the groups except single women. These increases are consistent with constraints on reducing net equity in housing without divesting entirely. The relatively constant levels of housing wealth observed in Table 1 result in large increases in housing-based ANW over the first decade of retirement, as housing value is spread over a shorter lifetime. Interestingly, the annuity value of financial assets increased for all of the marital status/gender groups, in spite of substantial decreases in the wealth value

\footnotetext{
${ }^{12} \mathrm{ANW}$ is the constant level of annual real consumption over the remaining expected lifetime that is supported by wealth holdings observed in each year. For married couples, ANW reflects periods when only one spouse survives.

${ }^{13}$ Based on the equivalence scale work reported in the National Research Council's study of poverty measurement (Citro and Michael, 1995), a couple is assumed to require 1.6 times the resources of a single person. We annuitize wealth over the life of the retired-worker and spouse assuming this equivalence scale. In effect we assume a joint and two-thirds survivor benefit for all assets, an allocation that reflects consumption needs during both the survival of the couple and the widow(er).
} 
TABLE 2

Mean Household Annuitized Net Wealth and Components

New Retired-Worker Beneficiaries,.1982 and 1991

\begin{tabular}{|c|c|c|c|c|}
\hline Wealth Component & Mean '82 & Mean '91 & $\%$ Change & $\begin{array}{c}\text { Contribution to } \\
\text { Total Change }\end{array}$ \\
\hline & \multicolumn{4}{|c|}{ (thousands of \$1994) } \\
\hline \multicolumn{5}{|c|}{ Married Women $(\mathrm{N}=1,505)$} \\
\hline Net Wealth & 22.5 & 23.1 & $2.3 \%$ & $100.0 \%$ \\
\hline Financial & 5.3 & 5.4 & 1.7 & 17.7 \\
\hline Housing & 3.3 & 4.9 & 48.4 & 307.3 \\
\hline Social Security & 10.9 & 10.2 & -6.2 & -128.7 \\
\hline Pensions & 3.1 & 2.6 & -16.3 & -96.3 \\
\hline \multicolumn{5}{|c|}{ Married Men $(N=2,634)$} \\
\hline Net Wealth & 24.9 & 27.9 & $12.0 \%$ & $100.0 \%$ \\
\hline Financial & 6.5 & 7.7 & 17.8 & 38.7 \\
\hline Housing & 3.7 & 5.3 & 40.3 & 50.5 \\
\hline Social Security & 11.1 & 11.8 & 6.5 & 24.1 \\
\hline Pensions & 3.6 & 3.2 & -11.1 & -13.3 \\
\hline \multicolumn{5}{|c|}{ Single Women $(\mathrm{N}=1,028)$} \\
\hline Net Wealth & 19.0 & 20.0 & $5.5 \%$ & $100.0 \%$ \\
\hline Financial & 3.5 & 3.9 & 10.9 & 36.6 \\
\hline Housing & 3.2 & 3.7 & 14.6 & 45.4 \\
\hline Social Security & 9.3 & 9.9 & 6.7 & 59.8 \\
\hline Pensions & 3.0 & 2.5 & -14.7 & -41.8 \\
\hline \multicolumn{5}{|l|}{ Single Men (N=412) } \\
\hline Net Wealth & 25.7 & 28.7 & $11.8 \%$ & $100.0 \%$ \\
\hline Financial & 8.2 & 9.8 & 19.9 & 53.7 \\
\hline Housing & 3.4 & 4.7 & 40.0 & 44.3 \\
\hline Social Security & 10.8 & 11.2 & 3.2 & 11.5 \\
\hline Pensions & 3.3 & 3.0 & -8.6 & -9.4 \\
\hline
\end{tabular}

of financial assets. For all but married women, the annuity value of Social Security wealth increased modestly. Because these benefits are both indexed and paid only as an annuity, the small change recorded over the period from 1982 to 1991 must be due to changes in either household composition that alter benefits or to benefit payments adjusted for additional earnings. ${ }^{14}$ The annuity value of pension wealth fell

\footnotetext{
${ }^{14}$ While all sample members initiated benefit receipt, some continued to work with earnings under the earnings limit in place at that time. Some in the sample began benefits but because of returns to work temporarily ceased receiving benefits. Additional covered earnings and interruptions in benefit receipt can increase the benefits
} 
for all of the groups, and by nearly 13 percent overall, consistent with the large decrease in the wealth value of expected pensions reported in Table 1 . The decrease in the annuity value of pension wealth is greater for women than for men, likely reflecting the loss of husband's pension upon widowhood (for married women in 1982) and the end of period-certain pension payments (for 1982 widows).

\section{ESTIMATES OF LEVELS AND CHANGE IN RESOURCE ADEQUACY}

In this section, we assess the extent to which the resources available to these newly retired workers are sufficient to enable them to meet both a private standard with ambiguous social implications (the level of individually-chosen preretirement consumption) and a standard with clear social implications (a poverty level or twice poverty level standard of living, taken to reflect the meeting of basic needs) over their remaining years of life. We report this assessment both at the time of retirement and ten years later.

To address the first standard of individual adequacy, we calculate a replacement rate defined as

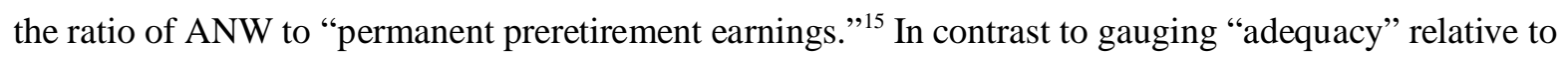
each individual's own past level of living, we compare the ANW to the poverty line. If ANW exceeds the poverty line standard, the household has sufficient resources to escape poverty throughout their expected remaining lifetime ${ }^{16}$ We calculate these two indicators of resource adequacy both at the time at which respondents first retired and ten years later.

for which an individual is eligible. The fall in annuitized Social Security wealth for married women most likely reflects the loss of benefits of deceased husbands.

${ }^{15}$ The estimation of our preretirement earnings measure, which is average earnings of the individual or couple from age 50 to one year prior to the respondent's first benefit receipt, is described in Appendix A. The estimation of preretirement earnings includes adjustments for covered earnings above the taxable maximum and for earnings in jobs not covered by Social Security. The earnings of couples are the average over the relevant period of the summed earnings for both spouses.

${ }^{16}$ For each household, the single-person equivalent ANW is compared to the single-person poverty line. For a couple a ratio of 1 or greater implies that adjusting for probability of widow(er)hood and accompanying changes in income, annuitized resources provides a level of income persistently above the poverty threshold. We use the revised poverty lines suggested by the National Research Council study of poverty (See Citro and Michael, 1995).. 
Column 1 of Table 3 summarizes the median levels of the individual adequacy replacement rate both in 1982 and 1991. Over all households, the median replacement rate was .83 in 1982, indicating that the resources available to the median retiree more than meet the commonly-accepted 70 percent maintenance-of-consumption standard. ${ }^{17}$ Over the first decade of retirement, the earnings replacement ratio for the median retiree maintained well-being, the ratio increasing only slightly from .83 to .84 . At the median, then, the initial measure of this standard provides a good estimate of the replacement ratio during the early years of retirement. These medians, however, indicate little about the distribution of replacement rates and the prevalence of shortfalls from the .7 standard. In 1982, about 32 percent of the new beneficiaries fail to meet this replacement standard. By 1991, ten years after retirement, the overall percentage increases to 35 percent. he median "poverty replacement rate" and a ratio based upon a standard of two-times the poverty line are also shown in column 1 for both 1982 and 1991 . At the time of retirement in 1982, the median poverty replacement rate is 3.05; the rate was slightly higher, 3.17, ten years later. The adequacy ratios based on twice the poverty line standard rose from 1.52 to 1.58 over the first decade of retirement. Using the twice-poverty standard, about 22 percent of all respondents had resources below the cutoff in both 1982 and 1991. It would appear that on average the overall social adequacy of resources is maintained during the first decade after retirement.

\section{ANW GAINERS AND DECLINERS}

While Table 3 implies stability in adequacy over the first decade of retirement for our sample, considerable upward and downward shifts in adequacy occur among individuals in our sample over the

\footnotetext{
${ }^{17}$ In the literature on savings adequacy, a standard of 70 percent of preretirement earnings is typically used as the level of post-retirement income necessary to maintain consumption. This 70 percent figure is supported by Boskin and Shoven (1987), who estimate that the "required" replacement rate is about 75 percent after adjusting for preretirement expenses in the form of saving, work related expenses, and taxes that are avoided in retirement years. Bernheim, Skinner and Weinberg (2001) using Consumer Expenditure Data, find reductions in "goods that are potentially complementary to work" (purchases of clothing, transportation and food away from home) do not vary substantially in percentage terms across income quartiles. (P. 852), thus supporting a uniform replacement standard across income groups.
} 
TABLE 3

Robustness of Results to Alternative Assumptions of Remaining Life Years, All Households

\begin{tabular}{lccc}
\hline & Expected Value & 70th Percentile & 90th Percentile \\
\hline $\mathbf{1 9 8 2}$ & & & \\
$\quad$ Median Annuitized Net Value & $\$ 19,040$ & $\$ 18,113$ & $\$ 17,201$ \\
Median Tobit Replacement Rate & 0.83 & 0.79 & 0.76 \\
Median Poverty Replacement & 3.05 & 2.90 & 2.75 \\
Median Two-times Poverty Replacement & 1.52 & 1.45 & 1.38 \\
Percent Not Meeting Maintenance of & & & 40.83 \\
Consumption Standard & 31.69 & 35.94 & 4.12 \\
Percent Not Meeting Poverty Standard & 3.75 & 3.91 & 25.35 \\
Percent Not Meeting Two-times Poverty & & & \\
Standard & 21.92 & 23.41 & $\$ 17,643$ \\
$\mathbf{1 9 9 1}$ & & & 0.75 \\
Median Annuitized Net Value & $\$ 19,785$ & $\$ 18,602$ & 2.82 \\
Median Tobit Replacement Rate & 0.84 & 0.79 & 1.41 \\
Median Poverty Replacement & 3.17 & 2.98 & 43.61 \\
Median Two-times Poverty Replacement & 1.58 & 1.49 & 5.29 \\
Percent Not Meeting Maintenance of & 34.68 & 38.81 & 25.20 \\
Consumption Standard & 4.75 & 5.00 & \\
Percent Not Meeting Poverty Standard & & & \\
Percent Not Meeting Two-times Poverty & 21.60 & 23.23 & \\
Standard & & & \\
\hline
\end{tabular}

1982 to 1991 period. Due to good or bad luck, or to wise or foolish choices, some individuals increased their wealth over time while others did not. Table 4 shows the percentage of the sample by replacement rate status (the earnings replacement ratio below and above .7 and ANW below and above twice the poverty threshold) in 1982 and 1991. Of those sample units who were above the .7 replacement rate in 1982, 20 percent did not meet that criterion ten years later. Of those who would have been judged to have inadequate savings by this standard at retirement, one third would have been judged to have adequate savings in the later year. While far fewer would have been judged inadequately prepared using twice the poverty standard, there was still considerable shift as 28 percent had ANW above that threshold in 1991 . 
Table 4

1982-91 Change in Status

(\% in 1982 group by 1991 status)

\begin{tabular}{lcc}
\hline & \multicolumn{2}{c}{1991} \\
\cline { 2 - 3 } 1982 & Meeting replacement $(>.7)$ & Not meeting replacement $(<.7)$ \\
\hline Meeting replacement $(>.7)$ & 80.1 & 19.9 \\
Not meeting replacement $(<.7)$ & 33.4 & 66.6
\end{tabular}

Meeting poverty standard $(>2 *$ pov)

Meeting standard ( $>$.2pov) $\quad$ Not meeting standard $(<.2 \mathrm{pov})$

Not meeting poverty standard (<2*pov)

Note: The .7 threshold is .7 of the ratio of ANW to average preretirement earnings. The poverty standard is that the ANW is equal to or greater than twice the poverty threshold.

In Table 5, we try to identify those characteristics that appear to place individuals most at risk of changes in our adequacy measures. The first column shows the percentage of the full sample with each characteristic. Columns 2 and 3 indicate the extent to which those with the indicated characteristics are represented among those whose ANW increased or decreased by more than 2.5 percent over the first decade of retirement (those for whom ANW remains stable are not separately identified). ${ }^{18}$ We label the first group as 'gainers' and the second as ‘decliners.' Over the entire sample of individuals and couples, 38 percent experienced a loss in ANW of more than 2.5 percent over the 1982-1991 period, and 53 percent experienced an increase in ANW of more than 2.5 percent.

The bold numbers in columns two and three indicate the higher value for a characteristic that is significantly different for decliner and gainers. For example, those who retired at an older age are more likely to be gainers than those who retired when younger, suggesting a continued disadvantage in the

\footnotetext{
${ }^{18}$ The ANW calculations in both 1982 and 1991 are calculated as single-person equivalents and so the ANW of persons who are married and single can be aggregated and compared.
} 
TABLE 5

Declines and Increases in ANW 1982-1991, by characteristics of respondent.

\begin{tabular}{|c|c|c|c|}
\hline & $\begin{array}{c}\text { All } \\
\text { Respondents }\end{array}$ & Decliners & Gainers \\
\hline Number of Observations & 5,579 & $\begin{array}{c}2,144 \\
(38.4 \%)\end{array}$ & $\begin{array}{c}2,942 \\
(52.7 \%)\end{array}$ \\
\hline Age & 65.9 & 65.7 & 66.1** \\
\hline \multicolumn{4}{|l|}{ Proportion with Characteristic } \\
\hline Single men & 0.07 & 0.07 & 0.07 \\
\hline Single women & 0.18 & 0.19 & $0.17 *$ \\
\hline Married men & 0.47 & 0.42 & $0.52^{* * *}$ \\
\hline Married women & 0.27 & 0.32 & $0.25^{* * *}$ \\
\hline Below poverty in 82 & 0.04 & 0.01 & $0.04^{* * *}$ \\
\hline Below near poor in 82 & 0.22 & 0.15 & $0.24 * * *$ \\
\hline Replacement rate $<.7$ in 82 & 0.32 & 0.22 & $0.38 * * *$ \\
\hline >.7 replacement rate in 82 & 0.68 & 0.78 & $0.62^{* * *}$ \\
\hline Nonwhite & 0.10 & 0.09 & 0.09 \\
\hline Widowed & 0.46 & 0.51 & $0.44^{* * *}$ \\
\hline Separated or divorced & 0.32 & 0.29 & 0.33 \\
\hline Married in '82; Single in '91 & 0.14 & 0.18 & $0.13^{* * *}$ \\
\hline Single in '82; Married in '91 & 0.01 & 0.02 & $0.01 * * *$ \\
\hline Respondent high school & 0.30 & 0.32 & $0.29 * *$ \\
\hline Respondent some college & 0.15 & 0.14 & $0.17 * * *$ \\
\hline Respondent college or higher & 0.13 & 0.12 & $0.15 * * *$ \\
\hline Spouse high school & 0.34 & 0.34 & 0.34 \\
\hline Spouse some college & 0.14 & 0.13 & 0.15 \\
\hline Spouse college or higher & 0.09 & 0.09 & 0.10 \\
\hline With Longest Job Uncovered & 0.18 & 0.19 & 0.18 \\
\hline Have Private Health Insurance & 0.82 & 0.84 & 0.83 \\
\hline Have Pension & 0.54 & 0.63 & $0.48^{* * *}$ \\
\hline Own Home & 0.80 & 0.83 & $0.81^{* *}$ \\
\hline Number of Children & 2.53 & 2.5 & 2.5 \\
\hline Years Worked & 31.5 & 31.0 & 31.8 $\mathbf{8}^{* *}$ \\
\hline Respondent Years Worked after Retirement & 2.29 & 1.80 & $2.70 * * *$ \\
\hline Spouse Years Worked after Retirement & 2.03 & 1.69 & $2.28 * * *$ \\
\hline Number of Health Problems & 2.17 & 2.23 & $2.08^{* * *}$ \\
\hline Spouse Health Condition & 0.42 & 0.44 & $0.40^{* * *}$ \\
\hline \% Wealth in 82 Accounted for by Asset Holdings & 14.9 & 19.2 & $12.8^{* * *}$ \\
\hline \% wealth in 82 Accounted for by Housing Wealth & 15.0 & 15.3 & 15.6 \\
\hline \% Wealth in 82 Accounted for by Pensions & 11.6 & 14.5 & $9.8^{* * *}$ \\
\hline $\begin{array}{l}\text { \% Wealth in } 82 \text { Accounted for by Social Security } \\
\text { Interaction: Private Health Insurance X Number of Respondent }\end{array}$ & 58.4 & 51.0 & 61.8 $8^{* * *}$ \\
\hline Health Problems & 1.8 & 1.8 & $1.7^{* * *}$ \\
\hline
\end{tabular}

Note: Percentage of gainers and decliners with characteristic is significantly different at ${ }^{*} \mathrm{p}<.1$; ${ }^{* *} \mathrm{p}<.05 ;{ }^{* * *} \mathrm{p}<.01$. 
economic prospects of those who receive benefits early. ${ }^{19}$ Several other patterns are also noteworthy. Married men accounted for 47 percent of the entire sample in 1982, but for only 42 percent of those whose ANW fell by more than 2.5 percent over the next ten years, and for a significantly higher proportion (52 percent) of those whose ANW rose by at least this amount. Both single and married (as of 1982) women, on the other hand, are disproportionately represented among those whose ANW declines. Those who changed marital status over the period, widow(er)s as of 1982, and those with little education and health problems (either respondent or spouse) tended to experience substantial declines in ANW. Those who worked more years, either prior to or after retirement, and those with a spouse who worked after retirement tend to be relative gainers; this is as expected since earnings after retirement reduce the need to draw down assets in order to support retirement.

Finally, those with low 1981 ANW relative to the poverty line and those with ANW below the .7 standard are more heavily represented among the gainers. The pattern of gainers and decliners by the composition of wealth holdings is consistent with the different concentration of those with ANW below and above the adequacy standards and by some shift toward the median or average. Those for whom Social Security wealth constitutes a relatively large share of 1982 asset holdings are gainers, while those with larger pension and financial asset shares tended to experience declines in ANW over the first decade of retirement. These patterns are also consistent with the higher risk of wealth declines for those retirees who hold a substantial share of their ANW in the form of more risky financial and pension assets, relative to Social Security wealth.

\footnotetext{
${ }^{19}$ Haveman, Holden, Wolfe and Wilson (2000) describe the relatively disadvantaged economic status of individuals who took benefits before age 65. The economic status of early retirees in this sample is a consequence of characteristics of these retirees (e.g., low education, or weak labor force attachment) that are related to both early benefit receipt and low economic status. Because the data are for recipients only, they do not permit an analysis of the causal relationship between economic status and retirement timing.
} 


\section{CORRELATES OF CHANGE IN ANW}

While the patterns in Table 5 are suggestive, they do not reveal the independent effect of individual characteristics on the change in resources (ANW) over the first decade of retirement. In Table 6, we explore how the change in ANW over the 1982-1991 period is related to the initial composition of assets, controlling for a set of retiree characteristics. We subdivide financial assets into three categoriesrelatively low risk financial assets, high risk financial assets, and equity in businesses and (non-home) property. The share of wealth that is accounted for by pension wealth is the excluded category. ${ }^{20}$ Other variables are introduced to control for sample selection and characteristics that would confound the relationship between asset share and ANW growth.

Having a large share of assets in either Social Security or housing is positively and strongly associated with the growth in resources over the first decade of retirement. Over a period during which the Consumer Price Index rose by nearly 50 percent, holding a large share of assets in these forms appears to contribute to both inflation protection and real growth. As was suggested by the simple comparisons in Table 5, those who retired when older, married men, those without health problems, and those with health insurance had statistically significant increases in both net wealth and ANW over the 1982-1991 period. ${ }^{21}$

Table 7 explores the correlates of changes in the log of ANW, focusing on individual characteristics with an a priori expected relationship to changes in ANW. We estimate this model using a 'value added' specification, including the level of ANW in 1982 (in log form) as a right hand side variable. The level of resources in 1982 is significantly associated with the growth in ANW over the

\footnotetext{
${ }^{20}$ We attempt to differentiate higher risk assets from less risky assets. In our grouping we define riskless financial assets as checking accounts, money market accounts, CD's, bonds, life insurance and similar assets. These are 8.4 percent of all ANW. Risky assets (2.1 percent of ANW) are defined to include stocks, shares in mutual funds, Keogh, IRAs. The third category of financial assets includes equity in housing other than the primary residence, and equity in businesses, professional practices, or farms (4.1 percent of ANW).

${ }^{21}$ These wealth-component results are quite robust across marital status and ANW groups. They are strongest for those whose ANW places them (over their remaining lifetime) between 2 and 4 times the poverty threshold, a group that accounts for 50 percent of our sample (estimates available from the authors).
} 
Table 6

Contributing Components to Percent Change in ANW Models with and without initial ANW

\begin{tabular}{|c|c|c|c|c|}
\hline \multirow[b]{2}{*}{ Dependent variable } & \multicolumn{4}{|c|}{ \% Change ANW } \\
\hline & Estimate & t-value & Estimate & t-value \\
\hline Intercept & -2.18 & -7.81 & -2.27 & -8.10 \\
\hline Share of ANW in risky assets & 0.24 & 1.57 & 0.38 & 2.41 \\
\hline Share of ANW in riskless assets & 0.37 & 3.68 & 0.38 & 3.74 \\
\hline Share of ANW in equities in property & 0.05 & 0.50 & 0.13 & 1.41 \\
\hline Share of ANW in social security & 0.69 & 11.14 & 0.61 & 9.22 \\
\hline Share of ANW in housing & 0.71 & 8.31 & 0.68 & 7.87 \\
\hline Age in 82 & 0.03 & 6.45 & 0.03 & 7.00 \\
\hline Single male & 0.02 & 0.63 & 0.03 & 0.74 \\
\hline Single female & -0.12 & -4.34 & -0.12 & -4.49 \\
\hline Married female & -0.11 & -4.60 & -0.10 & -4.45 \\
\hline Married in 82, single in 91 & 0.00 & 0.16 & 0.00 & 0.16 \\
\hline Single in 82, married in 91 & -0.15 & -1.89 & -0.15 & -1.82 \\
\hline Unexpected income received & 0.16 & 6.08 & 0.16 & 6.08 \\
\hline Number of health problems in 82 & -0.01 & -2.84 & -0.01 & -2.85 \\
\hline Additional health problems by 91 & -0.02 & -2.49 & -0.02 & -2.50 \\
\hline Spouse health condition in 82 & -0.03 & -1.48 & -0.03 & -1.53 \\
\hline Spouse health condition in 91 & -0.06 & -2.17 & -0.05 & -2.16 \\
\hline Private health insurance in 82 & 0.02 & 0.90 & 0.02 & 0.93 \\
\hline Private health insurance in 91 & 0.09 & 3.43 & 0.09 & 3.42 \\
\hline Annuitized wealth in 82 & & & 0.00 & -3.91 \\
\hline Number of observations & \multicolumn{2}{|c|}{5579} & \multicolumn{2}{|c|}{5579} \\
\hline F-value (p-value) & \multicolumn{2}{|c|}{$17.24(<.0001)$} & \multicolumn{2}{|c|}{$17.18(<.0001)$} \\
\hline Adjusted R-squared & \multicolumn{2}{|c|}{0.05} & \multicolumn{2}{|c|}{0.05} \\
\hline Mean change in ANW & \multicolumn{2}{|c|}{0.15} & \multicolumn{2}{|c|}{0.15} \\
\hline
\end{tabular}


TABLE 7

Regression Results for 91 LOG of Annuitized Net Wealth, Controlling for Log(ANW'82)

\begin{tabular}{|c|c|c|c|c|c|c|c|c|}
\hline \multirow[b]{2}{*}{ Dependent Variable } & \multicolumn{2}{|c|}{ Married Men } & \multicolumn{2}{|c|}{ Married Women } & \multicolumn{2}{|c|}{ Single Men } & \multicolumn{2}{|c|}{ Single Women } \\
\hline & $\begin{array}{l}\text { Parameter } \\
\text { Estimate }\end{array}$ & t-Value & $\begin{array}{l}\text { Parameter } \\
\text { Estimate }\end{array}$ & t-Value & $\begin{array}{l}\text { Parameter } \\
\text { Estimate }\end{array}$ & t-Value & $\begin{array}{l}\text { Parameter } \\
\text { Estimate }\end{array}$ & t-Value \\
\hline Intercept & -0.7022 & -3.08 & -1.3248 & -3.29 & -0.8299 & -1.31 & -1.6540 & -4.34 \\
\hline $\log \left(A N W^{\prime} 82\right)$ & 0.6335 & 36.39 & 0.6405 & 23.51 & 0.6891 & 14.76 & 0.6567 & 22.08 \\
\hline Age in 1982 & 0.0236 & 6.71 & 0.0334 & 5.30 & 0.0258 & 2.61 & 0.0337 & 5.74 \\
\hline Nonwhite & -0.1044 & -3.44 & -0.0538 & -1.29 & -0.1147 & -1.91 & -0.0904 & -2.39 \\
\hline Widowed & & & & & -0.1382 & -2.07 & 0.0163 & 0.43 \\
\hline Separated or divorced & & & & & -0.1096 & -1.81 & 0.0156 & 0.40 \\
\hline Married in ' 82 ; Single in '91 & 0.2445 & 10.48 & -0.2995 & -12.16 & & & & \\
\hline Single in ' 82 ; Married in '91 & & & & & -0.2811 & -4.07 & 0.1550 & 1.87 \\
\hline Respondent high school & 0.0433 & 2.27 & 0.1009 & 3.64 & 0.1230 & 2.12 & 0.0653 & 2.05 \\
\hline $\begin{array}{l}\text { Respondent some college } \\
\text { Respondent college or higher }\end{array}$ & $\begin{array}{l}0.1209 \\
0.2087\end{array}$ & $\begin{array}{l}4.84 \\
7.81\end{array}$ & $\begin{array}{l}0.2134 \\
0.2529\end{array}$ & $\begin{array}{l}5.95 \\
5.20\end{array}$ & $\begin{array}{l}0.0955 \\
0.2352\end{array}$ & $\begin{array}{l}1.29 \\
\mathbf{3 . 1 4}\end{array}$ & $\begin{array}{l}0.1566 \\
0.1798\end{array}$ & $\begin{array}{l}4.19 \\
4.06\end{array}$ \\
\hline Spouse high school & 0.0382 & 2.08 & 0.0096 & 0.34 & & & & \\
\hline Spouse some college & 0.0719 & 2.91 & 0.0273 & 0.69 & & & & \\
\hline Spouse college or higher & 0.0652 & 2.01 & 0.1315 & 3.04 & & & & \\
\hline Number of children & -0.0112 & -3.07 & -0.0182 & -3.01 & 0.0103 & 0.90 & -0.0084 & -1.14 \\
\hline Years worked & 0.0039 & 3.43 & 0.0044 & 3.59 & -0.0012 & -0.39 & 0.0059 & 3.76 \\
\hline Resp. years worked after ret. & 0.0101 & 4.40 & 0.0013 & 0.33 & 0.0237 & 3.31 & 0.0271 & 6.89 \\
\hline Sp. Years worked after ret. & -0.0017 & -0.69 & 0.0097 & 2.55 & & & & \\
\hline Longest job uncovered & -0.0186 & -0.99 & -0.0768 & -2.34 & 0.0305 & 0.52 & -0.1083 & -2.68 \\
\hline Number of health problems & -0.0094 & -2.43 & -0.0179 & -2.86 & -0.0167 & -1.58 & -0.0069 & -1.02 \\
\hline Spouse health condition & -0.0362 & -2.28 & 0.0028 & 0.12 & & & & \\
\hline Private health insurance & 0.0550 & 2.53 & 0.0554 & 1.74 & 0.0655 & 1.22 & 0.0537 & 1.61 \\
\hline Pension & -0.0152 & -0.89 & -0.0238 & -0.97 & 0.0639 & 1.23 & 0.0398 & 1.33 \\
\hline Home ownership & 0.1032 & 4.43 & 0.1151 & 3.32 & 0.1559 & 2.95 & 0.0731 & 2.45 \\
\hline Number of observations & \multicolumn{2}{|c|}{2,634} & \multicolumn{2}{|c|}{1,505} & \multicolumn{2}{|c|}{412} & \multicolumn{2}{|c|}{1,028} \\
\hline F-value (p-value) & 215.83 & $<.0001$ & 108.44 & $<.0001$ & 58.47 & $<.0001$ & 125.64 & $<.0001$ \\
\hline Adjusted R-squared & \multicolumn{2}{|c|}{0.62} & \multicolumn{2}{|c|}{0.59} & \multicolumn{2}{|c|}{0.70} & \multicolumn{2}{|c|}{0.67} \\
\hline Mean $\log \left(A N W^{\prime} 91\right)$ & \multicolumn{2}{|c|}{3.11} & \multicolumn{2}{|c|}{2.90} & \multicolumn{2}{|c|}{2.96} & \multicolumn{2}{|c|}{2.75} \\
\hline
\end{tabular}

Note: $t$ values in bold are significant at the $5 \%$ level of significance. 
period; the coefficient of less than unity suggests a convergence over time as higher ANW is associated with less growth in ANW.

Given initial ANW, what characteristics are correlated with increases or declines in ANW over the first ten years of retirement? For nearly all of the gender/marital status subgroups, the following characteristics are positively and significantly related to the growth of ANW from the time of retirement to ten years later:

- Age of benefit receipt, indicating continuing economic advantages accruing to those receiving benefits (retiring) at older ages

- Higher respondent and spouse education (if married)

- Being white (relative to nonwhite)

- More years worked prior to retirement

- More years worked after retirement

- Having fewer children (if married)

- Having better health, and spouse having fewer health problems (if married)

- Having private health insurance

- Being a home owner

Many of these relationships are consistent with the group gain/loss patterns observed in Table 5, and none are particularly surprising. Many of the characteristics are proxies for human capital, and therefore would be positively related to earnings during working years. To the extent that these determine earnings, pension coverage and benefits, and savings, their effect is already present in the 1982 ANW. Their importance in explaining the growth in resources after retirement controlling for the base level of resources suggests a continuing advantage of human capital in shaping post-retirement financial decisions 
and consumption choices. ${ }^{22}$ Other characteristics indicate fewer demands on private resources (e.g., having better health, and having private health insurance).

Interestingly, women whose longest job was not covered by Social Security showed slower growth in ANW over time. This may be a consequence of the noncovered pension offset rule that reduces Social Security spouse/widow benefits when a pension from noncovered work is received by a spouse. A change from being married at the time of retirement to being single 10 years later has a positive significant effect on ANW for men, but a negative significant effect for women. The increase in ANW for men is likely due to the relatively small loss in income when a wife (in contrast to a husband) dies and the fact that the loss of an (on average younger) wife sharply reduces the number of years of expected life (of the household) over which assets need to be spread, increasing their annuity value. Conversely, for women, the decrease in ANW due to the loss of a spouse after retirement is likely due to the larger retirement income loss suffered when husbands die and the shorter lifetime of the deceased husband compared to the wife. ${ }^{23}$ For men, the number of years after retirement that they continued to work is positively associated with increases in ANW over the first decade of retirement, but this relationship is present for only single women. However, for married women the change in ANW is positively and significantly associated with the number of years that their spouse worked after the woman began taking retirement benefits. ${ }^{24}$

\section{CORRELATES OF CHANGES IN RESOURCE ADEQUACY}

The analysis in Table 8 relates the characteristics of retirees to the change in resource adequacymeasured by the replacement rate ( = ANW/preretirement earnings)—over the 1982-1991 period. We

\footnotetext{
${ }^{22}$ Alternatively, retirees with more human capital may hold assets (including pensions) that grow more rapidly, which effect is not captured in our crude measure of base year resources.

${ }^{23}$ Parallel results exist for men and women who were single in 1982, and marry after retirement.

${ }^{24}$ This may reflect both post-retirement spousal earnings and the receipt own retired-worker benefits for which wives are eligible (prior to the retirement of their husbands).
} 
explore 'adequacy' because of both its direct policy relevance and the potential difference in results from Table 7 due to the comparison of ANW to a preretirement earnings standard. ${ }^{25}$ We, again, employ a value added approach, including the 1982 earnings replacement level. Coefficients indicate a change from that initial level. Statistically significant coefficients are shown in bold in the table.

The results in Tables 7 and 8 are similar. For all of the gender/marital status categories other than single women, the relationship between the base level of adequacy and the change in the earnings replacement ratio is positive but less than unity; those with higher replacement rates in 1982 experienced decreases in earnings replacement ratio over the first ten years of retirement, again suggesting that those with sufficient resources at the time of retirement were more able and likely to draw down their resources to support consumption during the retirement period. Becoming widowed during the first ten years of retirement diminishes the replacement ratio for married women, but now for married men as well, while entering a new marriage improves the replacement ratio only for women. Married men and women with more children tend to have decreases in the replacement ratio, suggesting that transfers of resources to offspring over the retirement period are not just from "extra” gains in ANW over this period. ${ }^{26}$ Having a college education increases the replacement ratio, supporting speculation that human capital continues to have value beyond effects on labor market earnings and pre-retirement savings decisions. Consistent with a pattern observed earlier, having a pension is associated with decreases in adequacy over the first decade of retirement. Finally, for single men and women, and for married men, increases in adequacy are positively associated with work after retirement.

\footnotetext{
${ }^{25}$ Correlates of change in the replacement ratio (Table 8) may differ from those of change in ANW (Table 7) because of different distributions of ANW and preretirement earnings. Note that the denominator of the replacement ratio is unchanged between 1982 and 1991 for each individual.

${ }^{26} \mathrm{An}$ interesting retirement research issue concerns the extent to which such intra-vivos transfers are intended at retirement, implying that measures of savings adequacy may be overstated
} 
TABLE 8

Regression Results for Tobit Replacement Rate in 1991, Controlling for 1982 Tobit Replacement Rate

\begin{tabular}{|c|c|c|c|c|c|c|c|c|}
\hline \multirow{2}{*}{$\begin{array}{l}\text { Dependent Variable } \\
\text { Regressor }\end{array}$} & \multicolumn{2}{|c|}{ Married Men } & \multicolumn{2}{|c|}{ Married Women } & \multicolumn{2}{|c|}{ Single Men } & \multicolumn{2}{|c|}{ Single Women } \\
\hline & $\begin{array}{l}\text { Parameter } \\
\text { Estimate }\end{array}$ & t-Value & $\begin{array}{l}\text { Parameter } \\
\text { Estimate }\end{array}$ & t-Value & $\begin{array}{l}\text { Parameter } \\
\text { Estimate }\end{array}$ & t-Value & $\begin{array}{l}\text { Parameter } \\
\text { Estimate }\end{array}$ & t-Value \\
\hline Tobit replacement rate '82 & 0.9529 & 88.35 & 0.8174 & 27.65 & 0.7393 & 9.33 & 1.0241 & 316.64 \\
\hline Married in ' 82 ; Single in '91 & -0.2042 & -2.76 & -0.7070 & -6.97 & & & & \\
\hline Single in ' 82 ; Married in '91 & & & & & 0.0699 & 0.23 & 1.0860 & 2.39 \\
\hline Respondent some college & 0.0806 & 1.03 & 0.3684 & 2.51 & -0.1093 & -0.34 & -0.1846 & -0.92 \\
\hline $\begin{array}{l}\text { Respondent college or } \\
\text { higher }\end{array}$ & 0.0964 & 1.17 & 0.0664 & 0.34 & 0.9176 & 2.93 & -0.0678 & -0.29 \\
\hline Number of children & -0.0194 & -1.68 & -0.0542 & -2.17 & 0.0093 & 0.18 & -0.0234 & -0.58 \\
\hline Years worked & 0.0014 & 0.38 & -0.0063 & -1.25 & -0.0366 & -2.83 & 0.0117 & 1.45 \\
\hline Resp. years worked after ret. & 0.0236 & 3.24 & -0.0192 & -1.15 & 0.1233 & 3.91 & 0.0595 & 2.76 \\
\hline Longest job uncovered & -0.0199 & -0.33 & -0.0228 & -0.17 & 0.2661 & 1.01 & -0.6117 & -2.76 \\
\hline Pension & -0.1089 & -2.10 & -0.1455 & -1.50 & 0.2269 & 1.08 & -0.0681 & -0.45 \\
\hline Number of observations & \multicolumn{2}{|c|}{2,634} & \multicolumn{2}{|c|}{1,505} & \multicolumn{2}{|c|}{412} & \multicolumn{2}{|c|}{1,028} \\
\hline F-value (p-value) & 428.7 & $<.0001$ & 43.76 & $<.0001$ & 9.7 & $<.0001$ & 5983.48 & $<.0001$ \\
\hline Adjusted R-squared & \multicolumn{2}{|c|}{0.7646} & \multicolumn{2}{|c|}{0.3625} & \multicolumn{2}{|c|}{0.2647} & \multicolumn{2}{|c|}{0.9900} \\
\hline Mean Tobit replacement rate & \multicolumn{2}{|c|}{1.2721} & \multicolumn{2}{|c|}{1.1166} & \multicolumn{2}{|c|}{1.2772} & \multicolumn{2}{|c|}{2.1623} \\
\hline
\end{tabular}

Note: t statistics in bold indicate statistical significance at the $5 \%$ level. 


\section{CONCLUSION}

We have estimated replacement rates based on permanent preretirement earnings both at the time of retirement (1982) and ten years later (1991). While our results have some implications for the measured adequacy of retirement savings, we focus in this paper on the stability of adequacy measures. Average estimates suggest stability in adequacy over the first ten years of retirement. In both 1982 and 1991 approximately the same proportion of our sample was below the replacement standard (.7 of preretirement earnings) and the poverty replacement rate standards. The median replacement rate and ratio of ANW to poverty thresholds show the same stability.

There is far greater instability in resource adequacy over time than is suggested by median levels. We find considerable shifting across adequacy thresholds; about a fifth of individuals who had been above the replacement rate standard upon retirement had moved below that standard ten years later.

Changes in both the aggregate value of resources (ANW) and the adequacy of assets relative to preretirement earnings are related to the characteristics of these retired people in expected ways. Preretirement economic advantages continued into retirement. Even controlling for initial levels of resources (and thus human capital effects on them), individuals who had more education, retired at an older age, had fewer children, were in better health, had private health insurance and owned a home tend to have greater increases in both ANW and the adequacy of resources. However, being widowed after retirement decreases the annuity value of assets and the replacement ratio for women, suggesting less provision for survivors than is consistent with continuing consumption needs of the survivor. Importantly, work after retirement increases ANW and the replacement ratio, implying that this may be an important component of retirement adequacy, perhaps even a planned component. Assuming that work ceases at retirement may underestimate retirement adequacy for an important percentage of individuals.

Our results have implications for discussion about the role of pensions in retirement adequacy. Our components-of-wealth analysis (Table 6) showed that having a larger share of retirement resources in 
inflation-adjusted Social Security and non-pension assets contributed positively to ANW and the replacement ratio over the retirement period.

Our conclusions about the adequacy of retirement resources for older Americans, and the change in resources during the decade after retirement must be tempered by a number of considerations. We may underestimate preretirement earnings for those with careers in noncovered employment or with deceased spouses. On the other hand, all studies that have covered work histories but not complete histories of earnings in noncovered work will face the same problem. In estimating ANW we used current U. S. life tables (by gender and race) for life expectancies; our estimates of resource adequacy are biased downwards for individuals who expect to live longer than average and biased upwards for those who expect to die sooner. While these may balance out in estimating average resource adequacy, our over- or under-estimates for individuals bias correlation results.

Further, we note the difficulty of judging “adequacy.” The 70 percent of prior earnings criterion is a crude value for gauging the level of available resources that may or may not be useful in private financial planning; it has little normative significance, especially for households with high standards of living (earnings) during preretirement years. Finally, although we observe our cohort of new retirees during the 1980s, we conclude that there is no strong evidence from other studies of wealth increases sufficient to suggest that our results are not still relevant. ${ }^{27}$

We believe that our findings contribute to the growing literature on the adequacy of resources of older Americans by documenting the importance of investigating changes in assets and their adequacy during retirement. Our results also have the potential to contribute to policy discussions regarding the potential alteration of social insurance programs so as to increase the adequacy of those whose resources fall below their own preretirement consumption patterns and, especially social norms regarding minimal consumption standards. Finally, the strong contribution of Social Security benefits toward establishing

\footnotetext{
${ }^{27}$ Using the Survey of Consumer Finance, we estimate that average net wealth in 1998 was no more than 10-20 percent greater than in the early-1980s. (Estimates are available from the authors.). These estimates are consistent with Wolff (2002).
} 
resource adequacy at the time of retirement and maintaining it over the following decade has implications for proposals that would substitute private retirement accounts for Social Security benefits. The apparent negative impact of private pension shares in ANW on the maintenance of retirement resources also has implications for proposals designed to increase the relative role of private savings in supporting retirement. 


\section{References}

Antonovics, Kate, Robert Haveman, Karen Holden, and Barbara Wolfe. 2000. “Attrition in the National Beneficiary Survey and Follow-Up, and Its Correlates” Social Security Bulletin 1(1) 2000: 1-7.

Bernheim, B. Douglas. 1992. “Is the Baby Boom Generation Preparing Adequately for Retirement?” New York: Merrill Lynch and Company.

Bernheim, B. Douglas, Jonathan Skinner, and Steven Weinberg. 2001. "What Accounts for the Variation in Retirement Wealth among U. S. Households?” American Economic Review 91 (4): 832-857.

Citro, Connie, and Robert Michael. 1995. Measuring Poverty: A New Approach. Washington, DC: National Academy Press.

Engen, Eric M., William G. Gale, and Cori E. Uccello. 1999. "The Adequacy of Household Saving.” Brookings Papers on Economic Activity 2: 65-187.

Grad, Susan. 1990. “Earnings Replacement Rates of New Retired Workers.” Social Security Bulletin 53(10): 2-19.

Gustman, Alan L., and Thomas L. Steinmeier. 1998. "Effects of Pensions on Saving: Analysis with Data from the Health and Retirement Study.” NBER Working Paper No.6681. Cambridge, MA: National Bureau of Economic Research.

Haveman, Robert, Karen Holden, Barbara Wolfe and Shane Sherlund. 2005. “Do Newly Retired Workers in the U.S. Have Sufficient Resources to Maintain Well-Being?” La Follette School Working Paper No. 2005-0012. http://www.lafollette.wisc.edu/publications/workingpapers

Maddala, George S. 1983. Limited-Dependent Qualitative Variables in Econometrics, Cambridge: Cambridge University Press.

Mitchell, Olivia, James Moore, and John Phillips. 2000. “Explaining Retirement Saving Shortfalls.” In Forecasting Retirement Needs and Retirement Wealth, edited by O. S. Mitchell, B. Hammond, and A. Rappaport. Pension Research Council. Philadelphia, PA: Univ. of Pennsylvania Press.

Moore, James and Olivia S. Mitchell. 2000. "Projected Retirement Wealth and Saving Adequacy”. In Forecasting Retirement Needs and Retirement Wealth, edited by O.S. Mitchell, B. Hammond, and A. Rappaport. Pension Research Council. Philadelphia, PA: University of Pennsylvania Press

U.S. Congressional Budget Office. 2003. “Baby Boomers’ Retirement Prospects: An Overview.” November, Washington, DC.

U.S. Department of Health and Human Services, Public Health Service, National Center for Health Statistics. 1985. Vital Statistics of the United States, 1982. Life Tables, Volume 11, Section 6. Hyattsville, Maryland.

Wolff, Edward N. 2002. Retirement Insecurity: The Income Shortfalls Awaiting the Soon-to-Retire. Washington, DC: Economic Policy Institute.

Ycas, M. A. 1992. “The New Beneficiary Data System: The First Phase.” Social Security Bulletin 55 (2): 20-35 


\section{Appendix A \\ Estimation of Annuitized Net Wealth and Preretirement Earnings}

\section{Annuitized Net Wealth (ANW)}

For both 1982 and 1991, we estimate the annuitized value of all assets over the remaining expected lifetime of respondents and, if married, of surviving spouses (again using race- and genderspecific life tables). Because our wealth estimates already reflect differences in inflation indexing, we use a uniform interest rate of 2.75 percent, taken to be the individual rate of time preference. The annuitized values we report are the single-person equivalent income that would be received if an individual or couple maintain a steady level of consumption potential over their remaining lifetimes, including the period when only one partner in a couple is expected to survive. ${ }^{28}$

\section{Permanent Preretirement Earnings}

To assess the adequacy of available resources, we relate the ANW of each individual and couple in our sample to their level of "permanent" preretirement earnings—-taken to reflect the income flow available to each respondent in the years before they retired. We estimate this indicator of preretirement living standards using the NBS-linked Social Security records on covered earnings for each respondent (and their spouse, if married) from age 50 to one year prior to the respondent's retirement (first benefit receipt). Because annual covered earnings records are capped at the maximum taxable earnings amount for each year, we use a Tobit estimation procedure to predict total earnings for individuals when the capped value is recorded; predicted earnings values are substituted for the capped values. Hence, permanent preretirement earnings equal the average of earnings that are below the cap and predicted

\footnotetext{
${ }^{28}$ Based on the equivalence scale work reported in the National Academy of Sciences study of poverty measurement (Citro and Michael, 1995), a couple is assumed to require 1.6 times the resources of a single person. We annuitize wealth over the life of the retired-worker and spouse assuming this equivalence scale. In effect we assume a joint and two-thirds survivor benefit for all assets, an allocation that reflects consumption needs during both the survival of the couple and the widow(er).
} 
earnings (in place of capped values) over the relevant years. For married couples, the recorded/predicted earnings of each spouse are summed for each relevant year.

Consider the total covered earnings for individual $i$ at time $t, y_{i t}^{*}$. Social Security contributions are withheld from $i$ 's earnings up to some taxable cap, $c_{t}$. Unfortunately, when $i$ 's covered earnings exceed the cap, we observe $y_{i t}=c_{t}$, rather than $y_{i t}=y_{i t}^{*}$. We therefore consider a model of the form

$$
y_{i t}=\left\{\begin{array}{l}
y_{i t}^{*} \text { if } y_{i t}^{*} \leq c_{t} \\
c_{t} \text { if } y_{i t}^{*}>c_{t}
\end{array},\right.
$$

where $y_{i t}$ is the observed covered earnings value for $i$. In order to estimate total covered earnings, we posit an intertemporal covered earnings profile of the form

$$
y_{i t}^{*}=\rho y_{i t-1}^{*}+z_{i t}^{\prime} \delta+\varepsilon_{i t} .
$$

Here, ${ }^{*}{ }^{*}$ it-1 is lagged (true) covered earnings, ${ }_{i t}$ is a vector of covariates (e.g., age, education, race, region, whether or not i was employed in the previous period, and spouse's age, spouse's education, and lagged spousal earnings, if married), ${ }^{\varepsilon_{i t}}$ is statistical error, and $\left[\rho, \delta^{\prime}\right]^{\prime}$ are parameters to be estimated.

We estimate the model using a dynamic, rolling-scheme, two-limit Tobit approach. The loglikelihood function and the formula for conditional expectations can be found in Maddala (1983). The Tobit model is useful in econometric analysis of data that is censored due to corner solutions or top- or bottom-coding. In our case, we observe a corner solution (nonnegativity constraint) at zero earnings and top-coding at the time-varying taxable maximum. We include lagged covered earnings as an explanatory variable in estimation, hence the term “dynamic.” Moreover, we include (up to) five lags of total covered earnings (beginning at age 50) as explanatory variables in estimation, hence the term "rolling-scheme." Under this approach, we estimate the model year-by-year, rather than as a panel, proceeding as follows. We first estimate our model for $t=1$ (year 1951), setting $y_{i 0}^{*}=0$ and excluding previous-year- 
employment indicator variables. We then use our parameter estimates to form Tobit predictions of total covered earnings, i.e., the conditional expectation of $y_{i 1}^{*}$. We can then estimate the model for $t=2$ (year 1952), using the predicted (lagged) $y_{i 1}^{*}$ and previous-year-employment indicator variables as additional explanatory variables. We use these estimates to form Tobit predictions of $y_{i 2}^{*}$. We continue in this manner through $t=31$ (year 1981).

We use the following algorithm to estimate total covered earnings. If reported covered earnings lie below the taxable maximum, we use the reported covered earnings value. When reported covered earnings are capped, we use NBS survey data on earnings during the last year on the last and longest jobs, if available for that particular individual and year. We assume these self-reported earnings provide better information on earnings in those individual years than do Tobit predictions. For years in which earnings are not self-reported, we use the maximum of our Tobit prediction and the taxable maximum. The taxable maximum amount, given by Administrative data, will be more accurate than the Tobit prediction if the Tobit prediction lies below the reported taxable maximum.

Preretirement earnings may now be calculated for the individual or couple as average (strictly positive) earnings between the year the retired-worker was age 50 and one year prior to his or her receipt of retirement benefits. We do not include years in which the individual's (or couple's) earnings are zero in calculating preretirement earnings. For married couples, we sum both individuals’ total covered earnings and average couple's earnings over the retired-worker's preretirement years. 
Table A

New Recipients of Social Security Retired Worker Benefits Characteristics of Sample

\begin{tabular}{|c|c|c|c|}
\hline Variable Means & $\begin{array}{c}\text { Married Men and } \\
\text { Women }\end{array}$ & Single Men & Single Women \\
\hline Distribution by Respondent type & $73.1 \%$ & $9.0 \%$ & $17.9 \%$ \\
\hline Age in 1982 & 65.8 & 66.2 & 66.8 \\
\hline \% Nonwhite & 8.0 & 18.5 & 14.9 \\
\hline \% Widowed & & 34.2 & 50.1 \\
\hline \%Separated or divorced & & 39.7 & 28.6 \\
\hline \%Respondent high school & 31.6 & 21.9 & 30.0 \\
\hline Respondent some college & 13.8 & 10.3 & 19.7 \\
\hline Respondent college or higher & 12.2 & 11.8 & 12.6 \\
\hline Spouse high school & 35.1 & & \\
\hline Spouse some college & 13.6 & & \\
\hline Spouse college or higher & 9.2 & & \\
\hline Number of children & 2.7 & 1.9 & 1.9 \\
\hline Years worked & 32.4 & 34.9 & 28.5 \\
\hline \% with longest job uncovered & 19.2 & 19.3 & 10.6 \\
\hline Number of health problems & 2.3 & 2.4 & 2.24 \\
\hline Spouse has a health condition & 41.6 & & \\
\hline \% with private health insurance & 83.7 & 69.2 & 76.6 \\
\hline \% with Pension & 55.8 & 42.7 & 45.6 \\
\hline Owning Home & 87.2 & 46.5 & 56.8 \\
\hline Preretirement earnings (PRE) & $\$ 24,095$ & $\$ 26,878$ & $\$ 20,113$ \\
\hline Standard deviation & $\$ 10,948$ & $\$ 15,947$ & $\$ 10,167$ \\
\hline Minimum & $\$ 336$ & $\$ 274$ & $\$ 24$ \\
\hline Maximum & $\$ 113,332$ & $\$ 146,369$ & $\$ 54,554$ \\
\hline Annuitized net wealth (ANW) & $\$ 24,741$ & $\$ 24,353$ & $\$ 19,509$ \\
\hline Standard deviation & $\$ 28,041$ & $\$ 25,986$ & $\$ 15,608$ \\
\hline Minimum & $\$ 2,006$ & $\$ 3,075$ & $\$ 2,687$ \\
\hline Maximum & $\$ 742,278$ & $\$ 295,385$ & $\$ 167,945$ \\
\hline Replacement rate (PRE) & 1.26 & 1.12 & 1.91 \\
\hline Standard deviation & 2.22 & 1.59 & 18.91 \\
\hline Minimum & 0.11 & 0.20 & 0.33 \\
\hline Maximum & 79.76 & 16.51 & 695.72 \\
\hline Replacement rate (PovLine) & 3.96 & 3.90 & 3.12 \\
\hline Standard deviation & 4.49 & 4.16 & 2.50 \\
\hline Minimum & 0.32 & 0.49 & 0.43 \\
\hline Maximum & 118.84 & 47.30 & 26.89 \\
\hline Number of observations & 5,935 & 731 & 1,452 \\
\hline
\end{tabular}




\section{CESifo Working Paper Series}

(for full list see www.cesifo-group.de)

1505 Peter A. Zadrozny, Necessary and Sufficient Restrictions for Existence of a Unique Fourth Moment of a Univariate GARCH(p,q) Process, July 2005

1506 Rainer Niemann and Corinna Treisch, Group Taxation, Asymmetric Taxation and Cross-Border Investment Incentives in Austria, July 2005

1507 Thomas Christiaans, Thomas Eichner and Ruediger Pethig, Optimal Pest Control in Agriculture, July 2005

1508 Biswa N. Bhattacharyay and Prabir De, Promotion of Trade and Investments between China and India: The Case of Southwest China and East and Northeast India, July 2005

1509 Jean Hindriks and Ben Lockwood, Decentralization and Electoral Accountability: Incentives, Separation, and Voter Welfare, July 2005

1510 Michelle R. Garfinkel, Stergios Skaperdas and Constantinos Syropoulos, Globalization and Domestic Conflict, July 2005

1511 Jesús Crespo-Cuaresma, Balázs Égert and Ronald MacDonald, Non-Linear Exchange Rate Dynamics in Target Zones: A Bumpy Road towards a Honeymoon - Some Evidence from the ERM, ERM2 and Selected New EU Member States, July 2005

1512 David S. Evans and Michael Salinger, Curing Sinus Headaches and Tying Law: An Empirical Analysis of Bundling Decongestants and Pain Relievers, August 2005

1513 Christian Keuschnigg and Martin D. Dietz, A Growth Oriented Dual Income Tax, July 2005

1514 Fahad Khalil, David Martimort and Bruno Parigi, Monitoring a Common Agent: Implications for Financial Contracting, August 2005

1515 Volker Grossmann and Panu Poutvaara, Pareto-Improving Bequest Taxation, August 2005

1516 Lars P. Feld and Emmanuelle Reulier, Strategic Tax Competition in Switzerland: Evidence from a Panel of the Swiss Cantons, August 2005

1517 Kira Boerner and Silke Uebelmesser, Migration and the Welfare State: The Economic Power of the Non-Voter?, August 2005

1518 Gabriela Schütz, Heinrich W. Ursprung and Ludger Wößmann, Education Policy and Equality of Opportunity, August 2005

1519 David S. Evans and Michael A. Salinger, Curing Sinus Headaches and Tying Law: An Empirical Analysis of Bundling Decongestants and Pain Relievers, August 2005 
1520 Michel Beine, Paul De Grauwe and Marianna Grimaldi, The Impact of FX Central Bank Intervention in a Noise Trading Framework, August 2005

1521 Volker Meier and Matthias Wrede, Pension, Fertility, and Education, August 2005

1522 Saku Aura and Thomas Davidoff, Optimal Commodity Taxation when Land and Structures must be Taxed at the Same Rate, August 2005

1523 Andreas Haufler and Søren Bo Nielsen, Merger Policy to Promote 'Global Players'? A Simple Model, August 2005

1524 Frederick van der Ploeg, The Making of Cultural Policy: A European Perspective, August 2005

1525 Alexander Kemnitz, Can Immigrant Employment Alleviate the Demographic Burden? The Role of Union Centralization, August 2005

1526 Baoline Chen and Peter A. Zadrozny, Estimated U.S. Manufacturing Production Capital and Technology Based on an Estimated Dynamic Economic Model, August 2005

1527 Marcel Gérard, Multijurisdictional Firms and Governments' Strategies under Alternative Tax Designs, August 2005

1528 Joerg Breitscheidel and Hans Gersbach, Self-Financing Environmental Mechanisms, August 2005

1529 Giorgio Fazio, Ronald MacDonald and Jacques Mélitz, Trade Costs, Trade Balances and Current Accounts: An Application of Gravity to Multilateral Trade, August 2005

1530 Thomas Christiaans, Thomas Eichner and Ruediger Pethig, A Micro-Level 'Consumer Approach’ to Species Population Dynamics, August 2005

1531 Samuel Hanson, M. Hashem Pesaran and Til Schuermann, Firm Heterogeneity and Credit Risk Diversification, August 2005

1532 Mark Mink and Jakob de Haan, Has the Stability and Growth Pact Impeded Political Budget Cycles in the European Union?, September 2005

1533 Roberta Colavecchio, Declan Curran and Michael Funke, Drifting Together or Falling Apart? The Empirics of Regional Economic Growth in Post-Unification Germany, September 2005

1534 Kai A. Konrad and Stergios Skaperdas, Succession Rules and Leadership Rents, September 2005

1535 Robert Dur and Amihai Glazer, The Desire for Impact, September 2005

1536 Wolfgang Buchholz and Wolfgang Peters, Justifying the Lindahl Solution as an Outcome of Fair Cooperation, September 2005 
1537 Pieter A. Gautier, Coen N. Teulings and Aico van Vuuren, On-the-Job Search and Sorting, September 2005

1538 Leif Danziger, Output Effects of Inflation with Fixed Price- and Quantity-Adjustment Costs, September 2005

1539 Gerhard Glomm, Juergen Jung, Changmin Lee and Chung Tran, Public Pensions and Capital Accumulation: The Case of Brazil, September 2005

1540 Yvonne Adema, Lex Meijdam and Harrie A. A. Verbon, The International Spillover Effects of Pension Reform, September 2005

1541 Richard Disney, Household Saving Rates and the Design of Social Security Programmes: Evidence from a Country Panel, September 2005

1542 David Dorn and Alfonso Sousa-Poza, Early Retirement: Free Choice or Forced Decision?, September 2005

1543 Clara Graziano and Annalisa Luporini, Ownership Concentration, Monitoring and Optimal Board Structure, September 2005

1544 Panu Poutvaara, Social Security Incentives, Human Capital Investment and Mobility of Labor, September 2005

1545 Kjell Erik Lommerud, Frode Meland and Odd Rune Straume, Can Deunionization Lead to International Outsourcing?, September 2005

1546 Robert Inklaar, Richard Jong-A-Pin and Jakob de Haan, Trade and Business Cycle Synchronization in OECD Countries: A Re-examination, September 2005

1547 Randall K. Filer and Marjorie Honig, Endogenous Pensions and Retirement Behavior, September 2005

1548 M. Hashem Pesaran, Til Schuermann and Bjoern-Jakob Treutler, Global Business Cycles and Credit Risk, September 2005

1549 Ruediger Pethig, Nonlinear Production, Abatement, Pollution and Materials Balance Reconsidered, September 2005

1550 Antonis Adam and Thomas Moutos, Turkish Delight for Some, Cold Turkey for Others?: The Effects of the EU-Turkey Customs Union, September 2005

1551 Peter Birch Sørensen, Dual Income Taxation: Why and how?, September 2005

1552 Kurt R. Brekke, Robert Nuscheler and Odd Rune Straume, Gatekeeping in Health Care, September 2005

1553 Maarten Bosker, Steven Brakman, Harry Garretsen and Marc Schramm, Looking for Multiple Equilibria when Geography Matters: German City Growth and the WWII Shock, September 2005 
1554 Paul W. J. de Bijl, Structural Separation and Access in Telecommunications Markets, September 2005

1555 Ueli Grob and Stefan C. Wolter, Demographic Change and Public Education Spending: A Conflict between Young and Old?, October 2005

1556 Alberto Alesina and Guido Tabellini, Why is Fiscal Policy often Procyclical?, October 2005

1557 Piotr Wdowinski, Financial Markets and Economic Growth in Poland: Simulations with an Econometric Model, October 2005

1558 Peter Egger, Mario Larch, Michael Pfaffermayr and Janette Walde, Small Sample Properties of Maximum Likelihood Versus Generalized Method of Moments Based Tests for Spatially Autocorrelated Errors, October 2005

1559 Marie-Laure Breuillé and Robert J. Gary-Bobo, Sharing Budgetary Austerity under Free Mobility and Asymmetric Information: An Optimal Regulation Approach to Fiscal Federalism, October 2005

1560 Robert Dur and Amihai Glazer, Subsidizing Enjoyable Education, October 2005

1561 Carlo Altavilla and Paul De Grauwe, Non-Linearities in the Relation between the Exchange Rate and its Fundamentals, October 2005

1562 Josef Falkinger and Volker Grossmann, Distribution of Natural Resources, Entrepreneurship, and Economic Development: Growth Dynamics with Two Elites, October 2005

$1563 \mathrm{Yu}-\mathrm{Fu}$ Chen and Michael Funke, Product Market Competition, Investment and Employment-Abundant versus Job-Poor Growth: A Real Options Perspective, October 2005

1564 Kai A. Konrad and Dan Kovenock, Equilibrium and Efficiency in the Tug-of-War, October 2005

1565 Joerg Breitung and M. Hashem Pesaran, Unit Roots and Cointegration in Panels, October 2005

1566 Steven Brakman, Harry Garretsen and Marc Schramm, Putting New Economic Geography to the Test: Free-ness of Trade and Agglomeration in the EU Regions, October 2005

1567 Robert Haveman, Karen Holden, Barbara Wolfe and Andrei Romanov, Assessing the Maintenance of Savings Sufficiency Over the First Decade of Retirement, October 2005 